\title{
PENGGUNAAN BIOCHAR DAN DEKOMPOSER DALAM PROSES PENGOMPOSAN LIMBAH KULIT BUAH KAKAO SERTA PENGKAYAAN MIKROB PELARUT FOSFAT (MPF) UNTUK MENINGKATKAN KUALITAS PUPUK ORGANIK
}

\section{Application of Biochar and Decomposers to The Composting Process of Cocoa Husk and Enrichment Using Phosphate Solubilizing Microbe to Improve The Quality Organic Fertilizer}

\author{
Haryanti1)*, Iswandi Anas ${ }^{2)}$, Dwi Andreas Santosa ${ }^{2)}$ dan Kurnia Dewi Sasmita ${ }^{2)}$ \\ 1) Program Studi Bioteknologi Tanah dan Lingkungan, Sekolah Pascasarjana, Institut Pertanian Bogor, Kampus \\ IPB Darmaga, Bogor, 16680 \\ ${ }^{2)}$ Departemen Ilmu Tanah dan Sumberdaya Lahan, Fakultas Pertanian, Institut Pertanian Bogor, Jl. Meranti \\ Kampus IPB Dramaga, Bogor 16680
}

\begin{abstract}
The use of cocoa husk waste by farmers is not optimal. In general, farmers only dispose of or immerse cocoa husk waste without processing it into quality organic fertilizer. This study aims to determine the influence of biochar and decomposers in accelerating the process of composting cocoa husk waste and improving the quality of organic fertilizers, and the effect of adding Phosphate Solubilizing Bacteria (BPF) to organic fertilizer derived from cocoa husk waste on the growth of cocoa seedlings (Theobroma cacao L.). The first phase of the research was carried out a factorial 2 factor design in the Completely Randomized Design i.e. Biochar (without biochar and 10\% biochar from the dry weight of organic fertilizer materials), and Decomposers (without decomposers and decomposers of $100 \mathrm{~g} \mathrm{~kg}^{-1}$ of organic fertilizer). The second phase of the study used a 3-factor factorial design in a Completely Randomized Design i.e. type of organic fertilizer (without organic fertilizer, organic fertilizer, organic fertilizer and biochar), inoculant Phosphate Solubilizing Bacteria (BPF), (without BPF inoculants, BPF A inoculants and BPF B inoculants), and dose of $P$ fertilizer (without $P$ fertilizer, $S P-36$ fertilizer $1 \mathrm{~g} P_{2} \mathrm{O}_{5}$, $S P$-36 fertilizer $2 \mathrm{~g} \mathrm{P}_{2} \mathrm{O}_{5}$, and natural phosphate fertilizer $\left.2 \mathrm{~g}_{2} \mathrm{O}_{5}\right)$. The results showed that the administration of biochar and decomposers did not accelerate the composting process. Provision of biochar and decomposers increases levels of humic acid. Giving natural phosphate $2 \mathrm{~g} \mathrm{P}_{2} \mathrm{O}_{5} / 2.2 \mathrm{~kg}$ BKM increases the height growth of cocoa seedlings. Application of organic fertilizer with biochar or without biochar on the inoculant treatment factors of BPF A and BPF B significantly increased the diameter of the cocoa seedling stem. Application of organic fertilizer increases the stem diameter, plant height, number of leaves of cocoa seedlings, root dry weight and dry weight of stem of cocoa seedlings.
\end{abstract}

Keywords: Composting, humic acid, phosphate solubilizing bacteria

\begin{abstract}
ABSTRAK
Penggunaan limbah kulit buah kakao oleh petani belum optimal. Umumnya petani hanya membuang atau membenamkan saja limbah kulit buah kakao tanpa diolah terlebih dahulu menjadi pupuk organik berkualitas. Penelitian ini bertujuan untuk mengetahui pengaruh biochar dan dekomposer dalam mempercepat proses pengomposan limbah kulit buah kakao dan memperbaiki kualitas pupuk organik, dan pengaruh penambahan Bakteri Pelarut Fosfat (BPF) ke dalam pupuk organik yang berasal dari limbah kulit buah kakao terhadap pertumbuhan bibit kakao (Theobroma cacao L.). Penelitian tahap pertama dilakukan dengan menggunakan rancangan faktorial 2 faktor dalam Rancangan Acak Lengkap (RAL) yaitu Biochar (tanpa biochar dan biochar 10\% dari bobot kering bahan pupuk organik), dan Dekomposer (tanpa dekomposer dan dekomposer $100 \mathrm{~g} \mathrm{~kg}^{-1}$ bahan pupuk organik). Penelitian tahap kedua menggunakan rancangan faktorial 3 faktor dalam Rancangan Acak Lengkap (RAL) yaitu jenis pupuk organik (tanpa pupuk organik, pupuk organik, pupuk organik dan biochar), inokulan Bakteri Pelarut Fosfat (BPF), (tanpa inokulan BPF, inokulan BPF A dan inokulan BPF B), dosis pupuk P (tanpa pupuk P, pupuk SP-36 $1 \mathrm{~g} \mathrm{P}_{2} \mathrm{O}_{5}$, pupuk SP-36 $2 \mathrm{~g} \mathrm{P}_{2} \mathrm{O}_{5}$, dan pupuk fosfat alam $2 \mathrm{~g} \mathrm{P}_{2} \mathrm{O}_{5}$ ). Hasil penelitian menunjukkan bahwa pemberian biochar dan dekomposer tidak mempercepat proses pengomposan. Pemberian biochar dan dekomposer meningkatkan kadar asam humat. Pemberian fosfat alam $2 \mathrm{~g} \mathrm{P}_{2} \mathrm{O}_{5} / 2.2 \mathrm{~kg}$ BKM meningkatkan pertumbuhan tinggi bibit kakao. Pemberian pupuk organik dengan biochar atau tanpa biochar pada faktor perlakuan inokulan BPF A dan BPF B meningkatkan secara nyata diameter batang bibit kakao. Pemberian pupuk organik meningkatkan diameter batang, tinggi tanaman, jumlah daun bibit kakao, berat kering akar dan berat kering batang bibit kakao.
\end{abstract}

Kata kunci: Pengomposan, asam humat, bakteri pelarut fosfat 


\section{PENDAHULUAN}

Indonesia menjadi penyumbang ketiga pasar kakao dunia setelah Pantai Gading dan Ghana. Produk sampingan berupa limbah kulit buah kakao berpotensi mencemari lingkungan dan dapat diatasi dengan penanganan teknologi yang tepat untuk dimanfaatkan. Produksi kakao (biji kering) Indonesia pada tahun 2016 mencapai 760,430 ton dengan luas areal 1,722,315 ha (Kementerian Pertanian, 2016). Limbah padat yang dihasilkan oleh limbah kulit buah kakao mencapai lebih dari $60 \%$ dari total produksi buah (Harsini dan Susilowati, 2010).

Limbah kulit buah kakao ini belum dimanfaatkan secara optimal oleh para petani. Umumnya para petani membuang atau membenamkan saja limbah kulit buah kakao tanpa diolah terlebih dahulu menjadi pupuk organik yang berkualitas.

Menurut Goenadi et al. (2000) kandungan hara mineral kulit buah kakao cukup tinggi, khususnya hara kalium dan nitrogen. Kandungan hara kompos yang dibuat dari limbah kulit buah kakao adalah $1.81 \% \mathrm{~N}, 26.61 \% \mathrm{C}$ organik, $0.21 \% \mathrm{P}_{2} \mathrm{O}_{5}, 6.08 \% \mathrm{~K}_{2} \mathrm{O}, 1.22 \% \mathrm{CaO}, 1.37 \%$ $\mathrm{MgO}, \mathrm{C} / \mathrm{N}$ rasio 14.70 dan KTK $44.85 \mathrm{cmol}^{+} / \mathrm{kg}$.

Biochar adalah arang yang terbuat dari residu tanaman, potongan kayu, atau pupuk kandang yang dibakar pada kondisi oksigen terbatas bahkan tanpa oksigen. Biochar disebut juga arang hayati yang bersifat porous, yang terbuat dari sisa mahluk hidup (Gani, 2009). Biochar dapat menambah kelembaban dan kesuburan tanah pertanian serta bisa bertahan ribuan tahun di dalam tanah. Dalam jangka panjang biochar tidak mengganggu keseimbangan karbon-nitrogen. Hal ini karena biochar mengikat $\mathrm{CO}_{2}$ hingga tidak terlepas ke atmosfir. Biochar mampu meningkatkan air dan nutrisi tersedia dalam tanah bagi tanaman (Balai Besar Penelitian Tanaman Padi, 2009). Salah satu fungsi biochar sebagai bahan pencampur (bulking agent) dalam proses pengomposan adalah memperbaiki proses humifikasi dan kualitas akhir kompos (Dias et al., 2010). Stabilitas karbon dalam biochar tinggi disebabkan strukturnya dibentuk oleh $\mathrm{C}$ aromatik dan heterosiklik sehingga resisten terhadap degradasi mikrob dan mineralisasi (Lehman dan Joseph, 2009). Penggunaan biochar untuk pengomposan di Indonesia telah diteliti oleh Gani (2007) untuk produksi pupuk organik sampah kota dan aplikasinya pada tanaman daun dewa.

Proses pengomposan dapat juga ditingkatkan dengan menggunakan dekomposer untuk mempercepat proses dekomposisi sisa-sisa tanaman yang mengandung lignin dan selulosa, meningkatkan biomassa dan aktivitas mikrob sehingga pemanfaatannya dapat meningkatkan kesuburan tanah. Dekomposer pengurai nitrogen dan karbon dari sisa jaringan tumbuhan atau hewan yaitu bakteri, fungi dan aktinomiset. Kajian pemanfaatan biochar dan dekomposer dalam pengomposan limbah kulit buah kakao belum pernah dilakukan sebelumnya. Penelitian ini dilakukan untuk mengetahui pengaruh biochar dan dekomposer dalam pengomposan limbah kulit buah kakao dalam mempercepat proses pengomposan serta memperbaiki kualitas kimia dan biologi dari pupuk organik. Pengkayaan pupuk organik limbah kulit buah kakao dengan MPF diharapkan mampu memberikan pengaruh terhadap sifat kimia dan biologi tanah serta meningkatkan efisiensi pemupukan $\mathrm{P}$ pada bibit kakao
(Theobroma cacao L) agar dapat menunjang pertumbuhan kakao yang optimal.

\section{BAHAN DAN METODE}

Penelitian ini dilaksanakan mulai dari April 2014 sampai dengan Agustus 2015. Kegiatan penelitian ini dilaksanakan di rumah pengomposan kebun percobaan Balai Penelitian Tanaman Industri dan Penyegar, Pakuwon, Sukabumi. Analisis penelitian di laksanakan di beberapa laboratorium yaitu: (i) Laboratorium Bioteknologi Tanah dan Laboratorium Kesuburan Tanah, Departemen Ilmu Tanah dan Sumberdaya Lahan, Fakultas Pertanian, Institut Pertanian Bogor (ii) Laboratorium Ekofisiologi, Balai Penelitian Tanaman Industri dan Penyegar, Pakuwon, Sukabumi (iii) Laboratorium Kimia Kayu dan Energi Biomassa Puslitbang Hasil Hutan, Bogor. Penelitian ini terdiri atas dua tahap. Penelitian tahap pertama untuk mengetahui pengaruh pemberian biochar dan dekomposer (perombak selulosa strain LD 140) koleksi Lab. Bioteknologi Tanah Departemen Ilmu Tanah dan Sumberdaya Lahan, Fakultas Pertanian, IPB dalam proses pengomposan. Bakteri Pelarut Fosfat (BPF) yang digunakan isolat indigenous hasil seleksi mikrob yang diisolasi dari tanah sekitar rizosfer perakaran tanaman kakao.

Proses pengomposan limbah kakao untuk meningkatkan kualitas pupuk organik secara kimia dan biologi. Bahan utama untuk pengomposan adalah kulit buah kakao dan kotoran sapi dengan perbandingan campuran 2:1 (w/w). Persentase campuran berdasarkan Bobot Kering Mutlak (BKM) bahan. Percobaan dilakukan dengan menggunakan rancangan faktorial 2 faktor dalam Rancangan Acak Lengkap (RAL) (Mattjik dan Sumertajaya, 2006).

Faktor-faktor perlakuan yang digunakan adalah sebagai berikut:
1. Biochar
: tanpa biochar dari bobot kering bahan pupuk organik (B0), biochar $10 \%$ dari bobot kering bahan pupuk organik (B1).
2. Dekomposer : tanpa dekomposer (D0), dekomposer 100 $\mathrm{g} \mathrm{kg}^{-1}$ bahan pupuk organik dengan kerapatan $\pm 106 \mathrm{SPK} \mathrm{ml}^{-1}(\mathrm{D} 1)$.

Kombinasi kedua faktor menghasilkan 4 kombinasi perlakuan dan setiap kombinasi perlakuan diulang sebanyak tiga kali sehingga menghasilkan 12 satuan percobaan. Untuk kontrol diberikan dekomposer $100 \mathrm{~g} \mathrm{~kg}^{-1}$ bahan pupuk organik dengan kerapatan 106 SPK $\mathrm{m}^{-1}$ yang sudah diautoklaf.

Penelitian tahap kedua dilakukan di rumah kaca dengan menggunakan media tanah inceptisol. Percobaan menggunakan rancangan faktorial 3 faktor dalam Rancangan Acak Lengkap (RAL) (Mattjik dan Sumertajaya, 2006).

Faktor-faktor perlakuan yang digunakan adalah sebagai berikut:

1. Jenis pupuk organik: tanpa pupuk organik (BO1), pupuk organik (BO2), pupuk organik dan biochar (BO3). 
2. Inokulan Bakteri Pelarut Fosfat (BPF): tanpa inokulan BPF (BPF0), inokulan BPF A (Burkholderia ambifaria B-SS1.2) (BPF1), inokulan BPF B (Burkholderia cepacia B-19.7) (BPF2).

3. Dosis pupuk $\mathrm{P}$ tanpa pupuk $\mathrm{P}$ (DP0), pupuk SP-36 1 $\mathrm{g} \mathrm{P}_{2} \mathrm{O}_{5}$ (DP1), pupuk P SP-36 2 g $_{2} \mathrm{O}_{5}$ (DP2), pupuk fosfat alam $2 \mathrm{~g} \mathrm{P}_{2} \mathrm{O}_{5}$ (DP3).

Kombinasi ketiga faktor menghasilkan 36 kombinasi perlakuan dan setiap kombinasi perlakuan diulang sebanyak tiga kali sehingga menghasilkan 108 satuan percobaan. Setiap ulangan terdapat 3 tanaman contoh sebagai sub ulangan yang ditanami benih tanaman uji (kakao) sebanyak 324 polibag. Dosis pupuk P sebesar 2 $\mathrm{g}_{2} \mathrm{O}_{5}$ polibag $^{-1}$. Setiap polibag diberikan pupuk dasar urea $2 \mathrm{~g}$ polibag $^{-1}$ dan $\mathrm{KCl} 2 \mathrm{~g}_{\text {polibag }}{ }^{-1}$ (rekomendasi PUSLITLOKA 2004) dengan mencampur rata pada media tanam. Pemberian pupuk organik $10 \%$ bobot kering media tanam. Pemberian BPF $10^{6} \mathrm{SPK} \mathrm{g}^{-1}$ pupuk organik untuk kontrol diberikan BPF $10^{6} \mathrm{SPK} \mathrm{g}^{-1}$ pupuk organik yang sudah diautoklaf.

Parameter yang diamati dalam pengomposan limbah kakao adalah suhu, pH dan kelembaban. Analisis $\mathrm{C} / \mathrm{N}$ dilakukan setiap 2 minggu sekali. Sampel diambil dari komposit 9 titik dalam setiap bak pengomposan (3 titik pada setiap kedalaman $10 \mathrm{~cm}, 30 \mathrm{~cm}$ dan $60 \mathrm{~cm}$ ). Analisis bahan baku pupuk organik yaitu kadar air (\%), kadar abu $(\%), \mathrm{C}$-organik (\%), $\mathrm{C} / \mathrm{N}$ ratio, $\mathrm{N}$ total $(\%), \mathrm{P}$ total $(\%)$, dan kadar $\mathrm{K}, \mathrm{Ca}, \mathrm{Fe}, \mathrm{Mg}, \mathrm{Mn}, \mathrm{Zn}$ total (ppm). Analisis pupuk organik yang sudah matang (1.5 bulan pengomposan) yaitu, kadar air (\%), kadar abu (\%), Corganik total, $\mathrm{N}$ total, $\mathrm{P}$ total, $\mathrm{K}, \mathrm{Ca}, \mathrm{Mg}, \mathrm{Na}, \mathrm{Fe}, \mathrm{Cu}, \mathrm{Mn}$ dan $\mathrm{Zn}$ total, $\mathrm{C}$ asam humat, populasi mikrob total, dan populasi mikrob selulolitik. Analisis bahan baku pupuk organik dilakukan untuk mengetahui karakteristik bahan baku pupuk organik sebelum proses pengomposan. Karakteristik awal bahan baku pupuk organik ditunjukkan pada Tabel 1.
Parameter yang diamati pada pertumbuhan bibit kakao terdiri dari tinggi tanaman $(\mathrm{cm})$, diukur dari pangkal batang hingga titik tumbuh, diameter batang $(\mathrm{mm})$, diukur pada $1 \mathrm{~cm}$ di atas pangkal batang dan jumlah daun (helai) (pengukuran setiap 2 minggu sekali selama 4 bulan). Data pengamatan dianalisis dengan menggunakan analisis varians (ANOVA) pada taraf nyata 5\%. Jika hasilnya signifikan maka akan diuji lanjut dengan menggunakan uji Duncan pada taraf nyata $5 \%$.

\section{HASIL DAN PEMBAHASAN}

\section{Bahaya Banjir}

Pengamatan pengomposan sampai hari ke-50 menunjukkan bahwa bahan kompos yang diberikan biochar mempunyai suhu yang lebih tinggi dibandingkan dengan yang tanpa biochar (Gambar 1). Suhu selama proses pengomposan berkisar antara $28{ }^{\circ} \mathrm{C}$ sampai dengan $53{ }^{\circ} \mathrm{C}$. Suhu fluktuatif dari hari ke-1 sampai dengan hari ke-25 karena adanya proses dekomposisi yang berlangsung dan proses pembalikan kompos. Suhu tertinggi pada perlakuan B1D0 (biochar tanpa dekomposer) $\left(53.0^{\circ} \mathrm{C}\right)$ dan B1D1 (biochar dan dekomposer) $\left(52.1^{\circ} \mathrm{C}\right)$ terjadi pada hari ketiga pengomposan. Hasil ini sejalan dengan yang dilaporkan oleh Dalzell et al. (1987) dimana pada tahap awal pengomposan suhu naik dengan cepat disebabkan mikrob memperbanyak diri dengan cepat. Hal ini juga disebabkan oleh panas yang dihasilkan dari proses perombakan bahan organik oleh mikrob (Djuarnani et al., 2005). Pada saat suhu mencapai $40{ }^{\circ} \mathrm{C}$ mikrob mesofilik digantikan oleh mikrob termofilik (Gaur, 1981). Menurut Setyorini et al. (2008) kenaikan suhu dalam timbunan bahan organik menghasilkan suhu yang menguntungkan mikrob termofilik. Setelah sebagian besar bahan organik terurai maka suhu akan berangsur-angsur turun dan pada akhir pengomposan suhu relatif stabil yang menandakan bahwa pupuk organik mendekati kematangannya.

Tabel 1. Analisis bahan baku pupuk organik

\begin{tabular}{lccc}
\hline Parameter & Kulit Buah Kakao & Kotoran Sapi & Biochar (Arang sekam) \\
\hline Kadar air (\%) & 8.94 & 7.29 & 7.53 \\
Kadar abu (\%) & 11.59 & 27.21 & 50.68 \\
Kadar C - Organik (\%) & 51.28 & 42.22 & 28.61 \\
C : N ratio & 71.61 & 27.41 & 40.19 \\
Kadar N total (\%) & 0,72 & 1.54 & 0.71 \\
Kadar P total (\%) & 0.15 & 0.28 & 0.11 \\
Kadar K total (\%) & 2.41 & 1.26 & 0.47 \\
Kadar Fe total (ppm) & 145 & 189 & 138 \\
Kadar Ca total (ppm) & 1,146 & 6,272 & 1,374 \\
Kadar Mg total (ppm) & 1,601 & 6,910 & 80 \\
Kadar Mn total (ppm) & 83 & 85 & 14 \\
Kadar Zn total (ppm) & 14 & 16 &
\end{tabular}




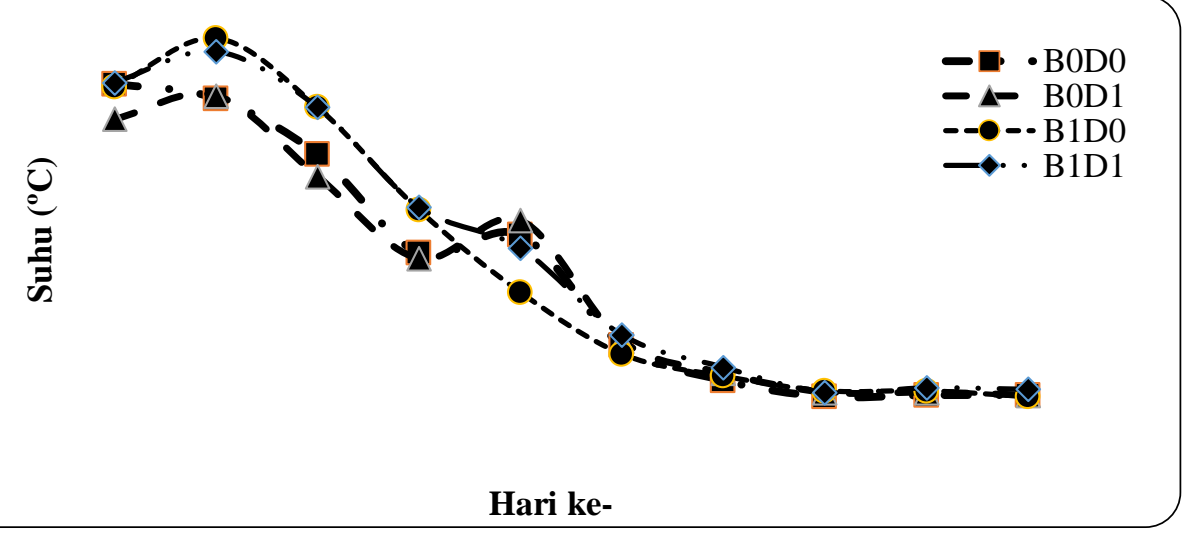

Keterangan : B0D0 (Kontrol); B0D1 (tanpa biochar dengan dekomposer); B1D0 (biochar tanpa dekomposer); B1D1 (biochar dan dekomposer)

Gambar 1. Suhu pupuk organik selama pengomposan

Hasil pengamatan $\mathrm{pH}$ sampai hari ke-45, dimana pH semua perlakuan dalam kisaran 6.0 sampai dengan 7.5 (Gambar 2). Penurunan $\mathrm{pH}$ terjadi pada hari ke-15 pada semua perlakuan disebabkan oleh bertambahnya produksi asam organik akibat dekomposisi bahan organik. Selanjutnya pada hari ke-21 pH semua perlakuan mengalami peningkatan dan cenderung netral seiring proses dekomposisi. Menurut Cooperband (2000) bakteri dekomposer berada dalam kisaran $\mathrm{pH} 6.0$ sampai dengan 7.5. $\mathrm{pH}$ merupakan salah satu faktor titik kritis bagi pertumbuhan mikrob yang mempengaruhi proses pengomposan (Simamora dan Salundik, 2006; Gazi et al., 2007). Apabila pH melebihi 7.5 maka kehilangan gas ammonia lebih mungkin terjadi dalam tumpukkan bahan organik. Menurut Heerden et al. (2002) suasana pengomposan yang alkalin akan memudahkan pecahnya ikatan lignin selulosa oleh enzim yang diproduksi oleh mikrob selulolitik. Peningkatan $\mathrm{pH}$ ini terjadi akibat meningkatnya jumlah kation-kation basa seperti kalium, kalsium dan magnesium serta adanya penghancuran protein dan pembebasan amoniak (Gaur, 1981). Adanya variasi $\mathrm{pH}$ menunjukkan terjadi interaksi yang berbeda dari dekomposer (Widiastuti et al., 2009). Peningkatan pH ini juga akibat adanya aktifitas mikrob yang mengkonversi asam organik yang telah terbentuk sebelumnya dan akhirnya stabil pada $\mathrm{pH}$ netral.

\section{Karakteristik Pupuk Organik yang Dihasilkan Setelah 4 Minggu}

Pemberian biochar menaikkan kadar asam humat sedangkan pemberian dekomposer juga mampu menaikkan kadar asam humat terutama pada pengomposan tanpa biochar (Tabel 2). Kandungan asam humat yang tinggi pada pupuk organik akan memengaruhi unsur hara dan populasi mikrob. Kualitas pupuk organik juga diidentikkan dengan kandungan unsur hara yang ada di dalamnya (Simamora dan Salundik, 2006). Menurut Gaur (1981) pupuk organik yang berkualitas mengandung 1.0\%-1.5\% nitrogen, $0.44 \%$ phospor dan $1.25 \%$ kalium. Kandungan asam humat yang tinggi pada pupuk organik akan memengaruhi unsur hara dan populasi mikrob. Semakin tinggi kandungan asam humat maka kualitas pupuk organik akan semakin baik karena dapat meningkatkan ketersediaan unsur hara yang sangat penting untuk pertumbuhan dan perkembangan tanaman (Hidayat, 2003). Oleh sebab itu pupuk organik seluruh perlakuan bisa digunakan untuk memperbaiki sifat kimia dan biologi tanah. Berdasarkan Permentan No.70 tahun 2011 tentang pupuk organik, hasil pengomposan seluruh perlakuan juga memenuhi kriteria yang ditetapkan mengenai pupuk organik.

$\mathrm{C} / \mathrm{N}$ rasio seluruh perlakuan telah mencapai nilai 19-20 pada hari ke-45 (Gambar 3). Nilai rasio C/N yang merupakan salah satu indikator yang menandakan proses dekomposisi dalam proses pengomposan pupuk organik berjalan dan merupakan salah satu indikasi kematangan kompos. Pemberian biochar pada proses pengomposan menaikkan rasio $\mathrm{C} / \mathrm{N}$ pada hari ke-15. Hal ini disebabkan bahan kompos yang diberi biochar mempunyai kandungan $\mathrm{N}$ total yang lebih rendah. Hal ini juga sejalan dengan penelitian Hua et al. (2009) dan Theeba et al. (2012) bahwa pemberian biochar yang berasal dari bambu dan yang berasal dari sekam padi memberikan efek positif dalam menurunkan kandungan $\mathrm{N}$ total selama proses pengomposan. Perubahan nilai rasio $\mathrm{C} / \mathrm{N}$ yang terjadi selama proses pengomposan diakibatkan adanya penggunaan karbon sebagai sumber energi dan hilang dalam bentuk $\mathrm{CO}_{2}$ sehingga kandungan karbon semakin lama semakin berkurang (Graves et al., 2007). Rochaeni et al. (2003) menyatakan bahwa nilai rasio $\mathrm{C} / \mathrm{N}$ pupuk organik matang berkisar 10-20. Namun demikian semua perlakuan tidak mempengaruhi waktu pengomposan dengan dilihat dari waktu yang sama untuk mencapai $\mathrm{C} / \mathrm{N}$ rasio 20 .

\section{Populasi Total Mikrob dan Mikrob Selulolitik Setelah 45 Hari}

Populasi total mikrob pada akhir pengomposan (setelah 45 hari) tertinggi pada perlakuan B1D0 (biochar tanpa dekomposer) (Gambar $4 \mathrm{~A}$ ). menunjukkan populasi mikrob selulolitik pada akhir pengomposan paling tinggi adalah pada perlakuan B1D1 (biochar dan dekomposer) (Gambar 4 B). Steiner et al. (2004) menyatakan bahwa dengan adanya biochar, keragaman, populasi dan aktivitas mikrob menjadi lebih besar. Biochar juga merupakan penyimpan karbon untuk jangka panjang dan tidak menganggu keseimbangan karbon-nitrogen. Karbon sebagai sumber energi bagi mikrob sehingga populasi total 
mikrob dalam pengomposan menjadi tinggi. Hal ini disebabkan biochar menyediakan habitat yang disukai oleh mikrob dan $\mathrm{pH}$ biochar juga sangat sesuai dengan mikrob sehingga mikrob mampu tumbuh dengan optimal. Hal ini didukung oleh Gani (2009) yang mengemukakan biochar dapat menyediakan habitat yang disukai mikrob, tapi tidak dikonsumsi oleh mikrob. Biochar juga dapat merangsang aktivitas dan merupakan tempat berkembang biak mikrob (Komarayati dan Indrawati, 2003).

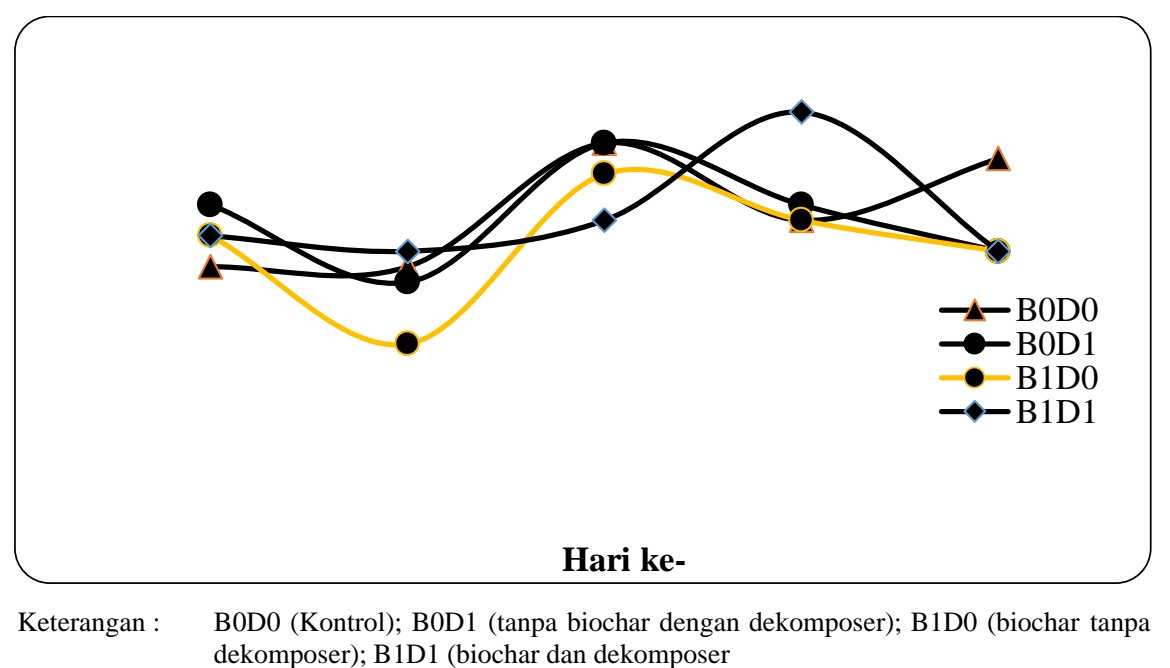

Gambar 2. pH pupuk organik selama pengomposan

Tabel 2. Karakteristik pupuk organik yang dihasilkan setelah minggu ke-4

\begin{tabular}{|c|c|c|c|c|c|}
\hline \multirow{2}{*}{ Parameter } & \multicolumn{4}{|c|}{ Perlakuan } & \multirow{2}{*}{$\begin{array}{c}\text { Permentan No.70 th } 2011 \\
\text { Standar Mutu }\end{array}$} \\
\hline & B0D0 & B0D1 & B1D0 & B1D1 & \\
\hline $\mathrm{pH}$ & $7.2^{\mathrm{a}}$ & $6.6^{\mathrm{a}}$ & $6.6^{\mathrm{a}}$ & $6.6^{\mathrm{a}}$ & $4-9$ \\
\hline Kadar abu $(\%)$ & $33.9^{\mathrm{a}}$ & $29.4^{\mathrm{a}}$ & $35.6^{\mathrm{a}}$ & $34.4^{\mathrm{a}}$ & - \\
\hline Kadar C - Organik (\%) & $38.3^{\mathrm{a}}$ & $40.9^{\mathrm{a}}$ & $37.4^{\mathrm{a}}$ & $38.0^{\mathrm{a}}$ & $\min 15$ \\
\hline $\mathrm{C}: \mathrm{N}$ ratio & $19.6^{\mathrm{a}}$ & $19.3^{\mathrm{a}}$ & $19.8^{\mathrm{a}}$ & $20.2^{\mathrm{a}}$ & $15-25$ \\
\hline Kadar $\mathrm{N}$ total $(\%)$ & $2.0^{\mathrm{a}}$ & $2.1^{\mathrm{a}}$ & $1.9^{\mathrm{a}}$ & $1.9^{\mathrm{a}}$ & \\
\hline Kadar P total (\%) & $0.2^{\mathrm{a}}$ & $0.2^{\mathrm{a}}$ & $0.2^{\mathrm{a}}$ & $0.2^{\mathrm{a}}$ & Untuk kadar $\mathrm{N}, \mathrm{P}$ dan $\mathrm{K}$ total $\min 4$ \\
\hline Kadar K total $(\%)$ & $3.9^{\mathrm{a}}$ & $4.2^{\mathrm{a}}$ & $3.2^{\mathrm{b}}$ & $3.2^{\mathrm{b}}$ & \\
\hline Kadar Fe total (ppm) & $1101^{\mathrm{a}}$ & $1081^{\mathrm{a}}$ & $1103^{\mathrm{a}}$ & $1107^{\mathrm{a}}$ & maks 9000 \\
\hline Kadar Na total (ppm) & $9802^{\mathrm{a}}$ & $10924^{\mathrm{a}}$ & $9019^{\mathrm{a}}$ & $9881^{\mathrm{a}}$ & - \\
\hline Kadar Ca total (ppm) & $6883^{\mathrm{a}}$ & $5163^{\mathrm{a}}$ & $5405^{\mathrm{a}}$ & $6164^{\mathrm{a}}$ & - \\
\hline Kadar Mg total (ppm) & $7743^{\mathrm{a}}$ & $8414^{\mathrm{a}}$ & $7503^{\mathrm{a}}$ & $7556^{\mathrm{a}}$ & - \\
\hline Kadar Cu total (ppm) & $46^{\mathrm{a}}$ & $40^{\mathrm{b}}$ & $32^{\mathrm{c}}$ & $32^{\mathrm{c}}$ & - \\
\hline Kadar Mn total (ppm) & $479^{\mathrm{a}}$ & $489^{\mathrm{a}}$ & $481^{\mathrm{a}}$ & $489^{\mathrm{a}}$ & maks 5000 \\
\hline Kadar Zn total (ppm) & $169^{\mathrm{a}}$ & $167^{\mathrm{a}}$ & $161^{b}$ & $163^{\mathrm{b}}$ & maks 5000 \\
\hline${ }^{*}$ Kadar Asam Humat (\%) & $10.5^{\mathrm{b}}$ & $12.0^{\mathrm{a}}$ & $11.3^{\mathrm{ab}}$ & $11.2^{\mathrm{ab}}$ & - \\
\hline
\end{tabular}

Keterangan : Angka dengan huruf yang berbeda pada baris yang sama menunjukkan perbedaan yang signifikan pada taraf 5\%. B0D0 (Kontrol); B0D1 (tanpa biochar dengan dekomposer); B1D0 (biochar tanpa dekomposer); B1D1 (biochar dan dekomposer)

Analisis dilakukan di Lab. Kesuburan Tanah, DITSL,Fakultas Pertanian, IPB dan *LIPI (2014)

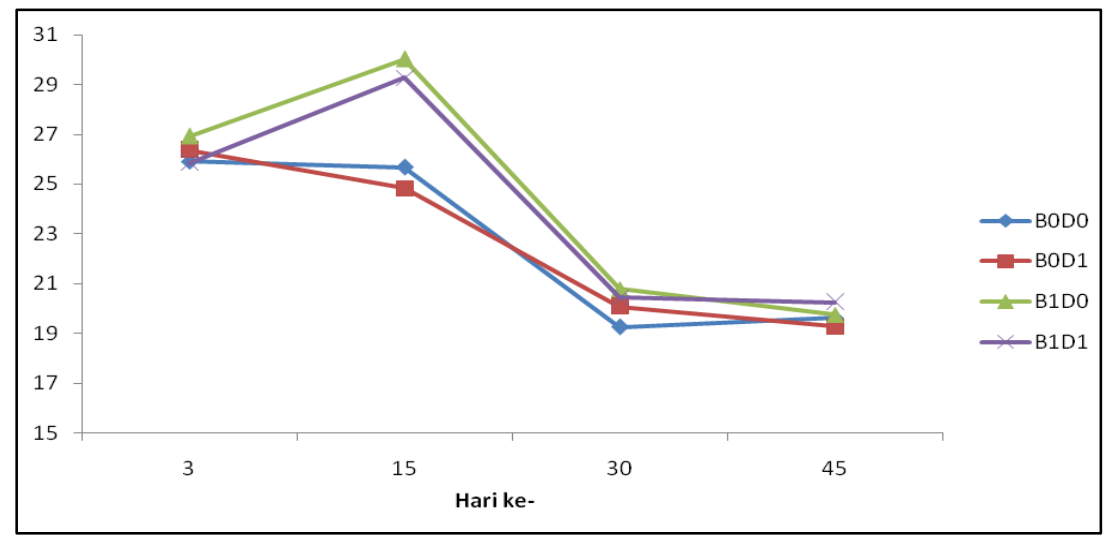

Keterangan : B0D0 (Kontrol); B0D1 (tanpa biochar dengan dekomposer); B1D0 (biochar tanpa dekomposer); B1D1 (biochar dan dekomposer).

Gambar 3. Perubahan $\mathrm{C} / \mathrm{N}$ rasio pupuk organik selama pengomposan 


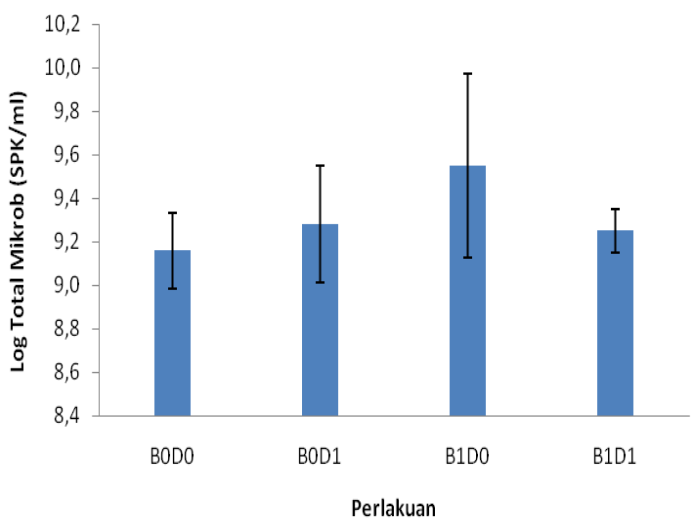

A

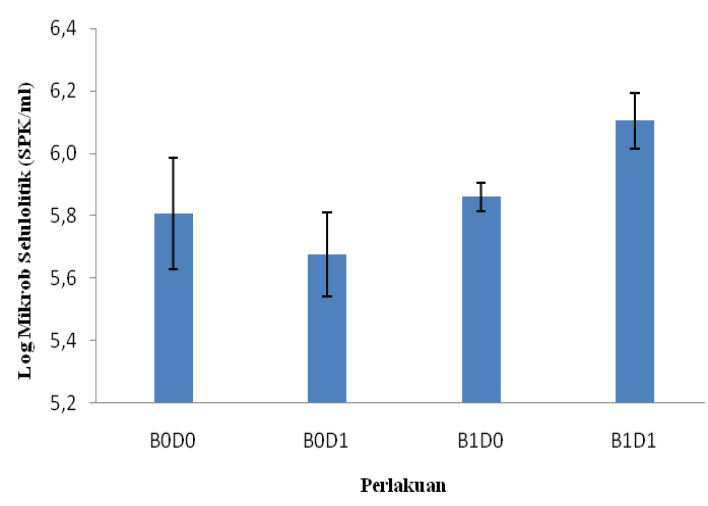

b

Keterangan : B0D0 (Kontrol); B0D1 (tanpa biochar dengan dekomposer); B1D0 (biochar tanpa dekomposer); B1D1 (biochar dan dekomposer)

Gambar 4. Populasi a) mikrob total. b) mikrob selulolitik dalam pupuk organik setelah 45 hari

Tabel 3. Pengaruh jenis pupuk organik terhadap diameter batang, tinggi tanaman dan jumlah daun bibit kakao umur 16 MST (Minggu Setelah Tanam)

\begin{tabular}{|c|c|c|c|}
\hline Jenis pupuk organik & Diameter batang $(\mathrm{mm})$ & Tinggi tanaman $(\mathrm{cm})$ & Jumlah daun (helai) \\
\hline Tanpa pupuk organik & $6.30^{\mathrm{b}}$ & $30.94^{\mathrm{b}}$ & $13.74^{\mathrm{b}}$ \\
\hline Pupuk organik tanpa biochar & $6.99^{\mathrm{a}}$ & $34.14^{\mathrm{a}}$ & $16.77^{\mathrm{a}}$ \\
\hline Pupuk organik dan biochar & $7.26^{\mathrm{a}}$ & $34.76^{\mathrm{a}}$ & $16.94^{\mathrm{a}}$ \\
\hline
\end{tabular}

Keterangan: Angka-angka pada kolom yang sama diikuti oleh huruf yang sama tidak berbeda nyata pada taraf $5 \%$.

Tabel 4. Pengaruh jenis pupuk organik dan inokulan BPF terhadap diameter batang bibit kakao umur 16 MST (Minggu Setelah Tanam)

\begin{tabular}{lccc}
\hline Perlakuan & Tanpa pupuk organik $(\mathrm{g})$ & Pupuk organik tanpa biochar $(\mathrm{g})$ & Pupuk organik dan biochar $(\mathrm{g})$ \\
\hline Tanpa BPF & $6.32^{\mathrm{de}}$ & $6.79^{\text {bcde }}$ & $7.58^{\mathrm{a}}$ \\
BPF A & $6.21^{\mathrm{e}}$ & $6.97^{\mathrm{abc}}$ & $7.39^{\mathrm{ab}}$ \\
BPF B & $6.37^{\text {cde }}$ & $7.22^{\mathrm{ab}}$ & $6.85^{\text {bcd }}$ \\
\hline
\end{tabular}

Keterangan: Angka-angka pada kolom/baris diikuti oleh huruf yang sama tidak berbeda nyata pada taraf $5 \%$.

Tabel 5. Pengaruh jenis pupuk organik terhadap berat kering akar dan berat kering batang bibit kakao umur 6 MST (Minggu Setelah Tanam)

\begin{tabular}{lcc}
\hline Jenis pupuk organik & Berat kering akar $(\mathrm{g})$ & Berat kering batang $(\mathrm{g})$ \\
\hline Tanpa pupuk organik & $2.64^{\mathrm{b}}$ & $1.60^{\mathrm{b}}$ \\
Pupuk organik tanpa biochar & $2.66^{\mathrm{b}}$ & $2.70^{\mathrm{a}}$ \\
Pupuk organik dan biochar & $3.20^{\mathrm{a}}$ & $2.53^{\mathrm{a}}$ \\
\hline
\end{tabular}

Keterangan: Angka-angka pada kolom yang sama diikuti oleh huruf yang sama tidak berbeda nyata pada taraf $5 \%$.

\section{Pengaruh Pupuk Organik, Biochar dan Bakteri Pelarut Fosfat (BPF) terhadap Pertumbuhan Bibit Kakao}

Penambahan pupuk organik nyata meningkatkan diameter batang, tinggi tanaman, dan jumlah daun bibit kakao. Penambahan pupuk organik dan biochar tidak nyata dibandingkan dengan penambahan pupuk organik tanpa biochar namun dapat menghasilkan diameter batang, tinggi tanaman dan jumlah daun bibit kakao yang paling baik. Hal tersebut menunjukkan adanya peran bahan organik terhadap pertumbuhan tanaman. Tanaman dapat tumbuh optimal jika unsur hara tersedia baik unsur hara makro (terutama $\mathrm{N}, \mathrm{P}$ dan $\mathrm{K}$ ) maupun unsur hara mikro yang penting untuk pertumbuhan tanaman. Menurut Lingga dan Marsono (2013) unsur hara nitrogen merupakan komponen penyusun asam amino, protein dan dan pembentukan protoplasma sel yang dapat berfungsi dalam merangsang pertumbuhan tinggi tanaman. Fosfor berperan terhadap pembelahan sel pada titik tumbuh yang berpengaruh pada tinggi tanaman. Unsur kalium juga berperan meningkatkan pertumbuhan tanaman yang berperan sebagai aktivator berbagai enzim. Penambahan unsur hara dari pemberian berbagai pupuk organik juga mempengaruhi pertumbuhan tanaman (Harjadi, 1996). Hal ini dapat dilihat pada Tabel 3.

Penambahan pupuk organik dan inokulan BPF dapat meningkatkan pertumbuhan diameter batang secara nyata dibanding tanpa pupuk organik (Tabel 4). Penambahan pupuk organik dengan biochar meningkatkan diameter batang bibit kakao sedangkan penambahan pupuk organik tanpa biochar dan penambahan tanpa pupuk organik pada perlakuan tanpa inokulan BPF tidak meningkatkan diameter batang bibit kakao. Penambahan biochar dan bakteri pelarut fosfat ke dalam pupuk organik meningkatkan diameter batang bibit kakao. Bahan organik yang terkandung dalam pupuk organik merupakan sumber karbon sebagai substrat pertumbuhan mikrob (Barea et al., 2005) sehingga aktivitas mikrob akan meningkat. Aktivitas mikrob yang meningkat berdampak positif terhadap proses 
mineralisasi unsur hara sehingga ketersediaan unsur hara bagi tanaman meningkat.

Penambahan pupuk organik meningkatkan berat kering akar dan berat kering batang bibit kakao. Unsur hara yang tersedia di dalam pupuk organik dapat menguatkan pertumbuhan diameter batang (Salisbury dan Ross, 1995) (Tabel 5). Simanungkalit et al. (2006) menyatakan bahwa pupuk organik memiliki fungsi kimia yang penting diantaranya adalah penyediaan unsur hara makro seperti $\mathrm{N}, \mathrm{P}, \mathrm{K}, \mathrm{Ca}, \mathrm{Mg}, \mathrm{S}$ dan unsur hara mikro seperti $\mathrm{Zn}, \mathrm{Cu}, \mathrm{Mo}, \mathrm{Co}, \mathrm{B}, \mathrm{Mn}$ dan Fe meskipun dalam jumlah yang sedikit. Tanaman akan tumbuh dengan baik bila hara yang dibutuhkan cukup tersedia dalam bentuk yang mudah diserap oleh perakaran tanaman. Kastono (2005) menyatakan bahwa pertumbuhan tanaman terjadi karena proses-proses pembelahan sel dan pemanjangan sel. Proses-proses tersebut memerlukan nutrisi dalam jumlah besar. Semakin membaiknya pertumbuhan tanaman akan dapat meningkatkan berat tanaman. Berat kering tanaman sangat dipengaruhi oleh optimalnya proses fotosintesis. Berat kering yang terbentuk mencerminkan banyaknya fotosintat sebagai hasil fotosintesis, karena bahan kering sangat tergantung pada laju fotosintesis. Asimilat yang lebih besar memungkinkan pembentukan biomassa tanaman yang lebih besar (Dwijosaputro, 1996).

\section{SIMPULAN}

Berdasarkan hasil penelitian pemberian biochar dan dekomposer tidak berpengaruh terhadap waktu pengomposan. Pemberian biochar menaikkan kadar asam humat dan pemberian dekomposer juga mampu menaikkan kadar asam humat terutama pada pengomposan tanpa biochar. Pemberian fosfat alam $2 \mathrm{~g}$ $\mathrm{P}_{2} \mathrm{O}_{5}$ meningkatkan pertumbuhan tinggi bibit kakao. Pemberian pupuk organik dengan biochar atau tanpa biochar pada faktor perlakuan inokulan BPF A dan BPF B meningkatkan secara nyata diameter batang bibit kakao. Pemberian pupuk organik meningkatkan secara nyata diameter batang, tinggi tanaman, jumlah daun bibit kakao, berat kering akar dan berat kering batang bibit kakao.

\section{DAFTAR PUSTAKA}

Balai Besar Penelitian Tanaman Padi. 2009. Biochar Penyelamat Lingkungan. Warta Penelitian dan Pengembangan Pertanian, 31(6).

Barea, J.M., M.J. Pozo, R. Azcon and C. Azcon-Aguilar. 2005. Microbial co-operation in the rhizosphere. J. Exp. Botany, 56(417):1761-1778.

Cooperband, L.R. 2000. Composting: art and science of organic waste conversion to a valuable soil resource. Laboratory medicine, 31(5):283-290

Dalzell, H.W., A.J. Biddlestone, K.R. Gray, J.F. Parr and Thurairajan. 1987. Pengolahan tanah: produksi dan penggunaan kompos dalam limbah padat di Indonesia: masalah atau sumber daya?. Yayasan Obor Indonesia, Jakarta.

Djuarnani, N., Kristian dan B.S. Setiawan. 2005. Cara Cepat Membuat Kompos. Agromedia Pustaka, Jakarta.
Dias, B.O., C.A. Silva., F.S. Higashikawa., A. Roig and M.A. Sanchez-Monedero. 2010. Use of biochar as bulking agent for the composting of poultry manure; effect on organic matter degradation and humification. Bioresource Technology, 101:1239. 1246.

Dwijosaputro. 1996. Pengantar Fisiologi Tumbuhan. Gramedia, Jakarta.

Gani, A. 2007. Konversi sampah organik menjadi komarasca (Kompos-biochar aktif-asap cair) dan aplikasinya pada tanaman daun dewa [Disertasi]. IPB. Bogor.

2009. Arang hayati biochar sebagai komponen perbaikan produktivitas lahan. Iptek Tanaman Pangan, 4:33-48.

Gaur, A.C. 1981. Compost organic recycling improving soil fertility through organic Recycling. FAO/UNDP Regional Project RAS/77/004. [Project field document]. p. 7-14.

Gazi, A.V., A. Kyriacou, M. Kotsou and K.E. Lasaridi. 2007. Microbial Community Dynamics and Stability Assessment during Green Waste Composting. Global NEST Journal, 9:35-41.

Goenadi, D.H., Siswanto and Y. Sugiarto. 2000. Bioactivation of poorly soluble phosphate rocks with a phosphorus-solubilizing fungus. Soil Science Soc. Am. J., 64:927-932.

Graves, R.E., G.M. Hattemer, D. Stettler and J.N. Krider. 2007. National Engineering Handbook. United States Department of Agriculture.

Harsini, T. dan Susilowati. 2010. Pemanfaatan kulit buah kakao dari limbah perkebunan kakao sebagai bahan baku pulp dengan proses organosol. Jurnal Ilmiah Teknik Lingkungan, 2:80-89.

Harjadi, S.S. 1996. Pengantar Agronomi. PT. Raja Grafindo Persada, Jakarta. 360 pp.

Herdeen, I., C. Cronje, S.H. Swart and J.M. Kotze. 2002. Microbial chemical and physical aspects of citrus waste composting. Biores. Techno., 81:71-76.

Hidayat, M.F. 2003. Pemanfaatan asam humat dan omega pada pemberian pupuk NPK terhadap pertumbuhan Gmelina arborea Roxb yang diinokulasi Cendawan Mikoriza Arbuskula (CMA) [Tesis]. IPB. Bogor.

Hua, L., W. Wu., Y. Liu and Y. Chen. 2009. Reduction of nitrogen loss and $\mathrm{Cu}$ and $\mathrm{Zn}$ mobility during sludge composting with bamboo char amandmend. Journal Enviromental Silence Pollution Research, 16:1-9.

Kastono, D. 2005. Tanggapan pertumbuhan dan hasil kedelai hitam terhadap penggunaan pupuk organik dan biopestisida gulma siam (Chromolaena odorata). J. Ilmu Pertanian, 12:103-116.

Kementerian Pertanian. 2016. Komoditas Pertanian dan Subsektor Perkebunan. [Outlook Kakao]. Pusat 
Data dan Sistem Informasi, Sekretariat Jenderal, Jakarta.

Komarayati, S. dan I. Indrawati. 2003. Isolasi dan identifikasi mikroorganisme dalam arang kompos. Buletin Penelitian Hasil Hutan, 21:251-258.

Lehman, J. and S. Joseph. 2009. Biochar for environmental management: an introduction. In Lehman J. S. Joseph (Ed.). Biochar for Environmental Management: Science and Technology. Earthscan. p. 1-9.

Lingga, P. dan Marsono. 2013. Petunjuk Penggunaan Pupuk. Penebar Swadaya, Jakarta.

Mattjik, A.A. dan M. Sumertajaya. 2006. Perancangan Percobaan dengan Aplikasi SAS Minitab. IPB Press, Bogor.

Rochaeni, A., R. Deni dan H.P. Karunia. 2003. Pengaruh agitasi terhadap proses pengomposan sampah organik. Infomatek, 5:177-186.

[PUSLITLOKA] Pusat Penelitian Kopi dan Kakao. 2004. Panduan Lengkap Budidaya Kakao. Pusat Penelitian Kopi dan Kakao Indonesia. PT. Agromedia Pustaka, Jakarta.

Salisbury, F.B. dan C.W. Ross. 1995. Fisiologi tumbuhan. Jilid I Ed. Ke-4. D.R Lukman, Sumaryono. penerjemah; S. Niksolihin (Ed). Penerbit ITB, Bandung. Terjemahan dari: Plant Physiology.

Setyorini, D., R. Saraswati dan E.K. Anwar. 2008. Kompos. Pupuk Organik Pupuk Hayati. Balai
Besar Penelitian dan Pengembangan Sumberdaya Lahan Pertanian, Bogor. p. 11-37.

Simamora, S. dan Salundik. 2006. Meningkatkan Kualitas Kompos. Agromedia, Jakarta.

Simanungkalit, R.D.M., D.A. Suriadikarta, R. Saraswati, D. Setyorini dan W. Hartatik. 2006. Pupuk organik dan pupuk hayati [bibliografi]. Balai Penelitian Tanah Balai Besar Penelitian dan Pengembangan Sumberdaya Lahan Pertanian Badan Penelitian dan Pengembangan Pertanian, Bogor.

Steiner, C., W.G. Teixeira., J. Lehmann and W. Zech. 2004. Microbial response to charcoal amendmend of highly weathered soils and Amazonian Dark Earth in Central Amazonia [preliminary results]. In B Glaser and W.I. Woods (Eds.). Amazonian Dark Earths: Explorations in Time and Space, Springer, Berlin, Germany. p. 195-212.

Theeba, M., T. Robert., Bachmann., Z.I. Illani., M. Zulkefli., M.H.A. Husni and A.W. Samsuri. 2012. Characterization of local mill rice husk charcoal and its effect on compost properties. Malaysian Journal of Soil Science, 16:89-102.

Widiastuti, H., Isroi dan Siswanto. 2009. Keefektifan beberapa dekomposer untuk pengomposan limbah sludge pabrik kertas sebagai bahan baku pupuk organik. Jurnal Selulosa, 44:99-110. 